\title{
Evaluation of Response of Potato on Different Doses of Nitrogen and Potassium in Growth and Yield
}

\author{
D.P. Mechao* and Sunita Bhandari
}

Department of Agronomy, Uttaranchal (P.G.) College of Bio-Medical sciences \& Hospitals, H.N.B Garhwal University, Srinagar(Garhwal)-246 174, Uttarakhand, India

*Corresponding author

\section{Keywords}

Potato, Nitrogen, Potassium, Growth, Yield, Yield attributes

\section{Article Info}

Accepted:

18 October 2018

Available Online:

10 November 2018

\section{A B S T R A C T}

Field investigation was carried out to evaluate the Response of potato on different doses of nitrogen and potash levels on growth and yield parameters in potato var. Kufrikundan. The experiment compromised of 8 treatments where control is $\mathrm{T}_{1}\left(\mathrm{~N}_{0} \mathrm{~K}_{0}\right)$, and other treatments are $\mathrm{T}_{2}\left(\mathrm{~N}_{1} \mathrm{~K}_{0}\right), \mathrm{T}_{3}\left(\mathrm{~N}_{2} \mathrm{~K}_{0}\right), \mathrm{T}_{4}\left(\mathrm{~N}_{3} \mathrm{~K}_{0}\right), \mathrm{T}_{5}\left(\mathrm{~N}_{0} \mathrm{~K}_{1}\right), \mathrm{T}_{6}\left(\mathrm{~N}_{0} \mathrm{~K}_{2}\right), \mathrm{T}_{7}\left(\mathrm{~N}_{2} \mathrm{~K}_{1}\right)$ and $\mathrm{T}_{8}\left(\mathrm{~N}_{2} \mathrm{~K}_{3}\right)$ was applied to all the treatments. The treatments were laid in Randomized Block Design (RBD) with 3 replication of each treatment. The variety of potato used was Kufrikundan. Observations on growth, yield attributing characters and yield recorded and analysed statistically. All the treatments gave better response to growth and yield attributes over control. Among the various treatment $\mathrm{T}_{8}\left(\mathrm{~N}_{3} \mathrm{~K}_{2}\right)$ proved superior with increased plant height, number of leaves per plant, number of stolon per plant, fresh and dry weight of tuber per plant, fresh and dry weight of shoot, fresh and dry weight of root per plant, tuber yield per hectare. Next to $\mathrm{T}_{8}$ the treatment $\mathrm{T}_{7}\left(\mathrm{~N}_{2} \mathrm{~K}_{1}\right)$ showed better response to growth attributes, tuber yield. It is concluded that the application of Nitrogen and Potassium showed the significant difference. Hence it is suggested that the nutrients Nitrogen and Potassium promotes the growth and yield attributes of potato.

\section{Introduction}

Potato (Solanum tuberosum L.) is one of the most important vegetable crop growing in the world, belongs to family Solanaceae. Potato is not only a rich source of carbohydrates and calories but also furnishes high quality of amino acids, Vitamin $\mathrm{B}$, Vitamin $\mathrm{C}$ and minerals. One hundred grams of potato tuber contains $80 \%$ moisture, $20 \%$ dry matter, $14 \%$ starch, 20\% sugar, $2 \%$ protein, $1 \%$ mineral salts, $0.61 \%$ fiber and $0.1 \%$ fat (Anonymous, 2002).
Potato (Solanum tuberosum L.) is the most important food crop of the world. Potato is an important tuber crop rich in carbohydrates (22.6 g per $100 \mathrm{~g}$ of edible portion), minerals $(\mathrm{Ca}, \mathrm{Mg}, \mathrm{Cu}, \mathrm{Fe}, \mathrm{P}, \mathrm{K}$ and $\mathrm{Na}$ ), and vitamin $\mathrm{C}$ $(17 \mathrm{mg})$ and contains 97 kilo calories energy per $100 \mathrm{~g}$ of edible matter and it is also used for several industrial purposes such as for production of starch, alcohol, dextrin, glucose, dyes etc.

It is consumed as vegetable alone or mixed with other vegetables such as brinjal, cabbage, 
tomato, beans, cauliflower etc. It is used to make chips and other products (Thamburaj and Narendra Singh, 2005).

The effects of $\mathrm{N}$ and $\mathrm{K}$ on potato were reported by many workers in different soil and climatic conditions (Mondal et al., 2007; Brar and Kaur, 2006; Sharma and Sood, 2002). However most of the research work is reported from Northern parts of India. The studies pertaining to the nutrition yield and quality of potato as influenced by the application of $\mathrm{N}$ and $\mathrm{K}$ is very meager in Andhra Pradesh. In spite of low acreage, the crop is meeting the vegetable demand of Hyderabad, Ranga Reddy and surrounding districts and is fetching good price to the potato growers.

Hence, keeping in view the above facts an experiment entitled "Evaluation of Response of potato on different doses of nitrogen, potassium and their interactions in growth and yield was conducted.

\section{Materials and Methods}

The experiment was carried out at the Experimental Field of Uttaranchal (P.G.) College of Bio-medical Sciences and Hospital, The experiment was laid out in randomized block design with 8 treatments consisting of different levels of nitrogen and potash viz., 0 (control), 60,120,180 kg N/ha and $50 \mathrm{~kg}$ and 0 (control), 60 and $120 \mathrm{~kg} \mathrm{~K}_{2} \mathrm{O} / \mathrm{ha}$ which were replicated 3 times. Nitrogen and potash was applied in the form of Urea, and M.O.P, respectively. Recommended dose of phosphorus i.e. $80 \mathrm{~kg} / \mathrm{ha}$ of each was applied. The test variety used was Kufrikundan planted in furrow of $60 \mathrm{~cm}$ apart with a spacing of 25 $\mathrm{cm}$. The soil of experimental field was clayey loam. Full doses of phosphorus and potash were applied through single super phosphate and MOP respectively as basal dose at the time of planting, whereas nitrogen was applied in each plot in split doses as per the treatments. Half dose of the nitrogen of each treatment was applied through urea as basal dressing and remaining half dose was applied at the time of first earthing up. 35 days after planting the remaining dose of nitrogen was applied through urea. Earthing up was done at 35 days after planting (DAP). Weeding was done at the time of earthing to remove the weeds. Six irrigations were provided during the entire crop growth period. Although, irrigation was given by flood irrigation method. All the recommended package and practices were followed to raise a healthy crop.

\section{Results and Discussion}

Data presented in Table 1 reveals that the treatment effect was found to be significantly different for plant height. Increasing trend in case of plant height was observed with the increase in nitrogen and potash levels. At 30, 50, 70 and 90 DAS, It was observed that the plant height with maximum height were 24.60 , $32.33,38.67$ and $38.33 \mathrm{~cm}$, respectively. In general, an increase in nitrogen and potash influenced the height of the plant. Significantly maximum number of leaves was found on application of $180 \mathrm{~kg} \mathrm{~N}, 120 \mathrm{~kg}$ potash / hectare. Maximum number of leaves recorded at 30, 50, 70 and 90 DAS were $19.00,31.80,35.38$ and 29.38 respectively. The increase in plant height and number of leaves with increase in nitrogen and potash. Enhancing the fresh weight of shoot with maximum being recorded under $180 \mathrm{~kg} \mathrm{~N} / \mathrm{ha}$ and $120 \mathrm{~kg} \mathrm{~K} / \mathrm{ha}$ (144.86 g). Maximum dry weight of shoot per plant $(24.54 \mathrm{~g})$ was noted in the treatment 180 and $120 \mathrm{~kg} / \mathrm{ha}$ of $\mathrm{N}$ and $\mathrm{K}_{2} \mathrm{O}$.

On the perusal of yield attributing data presented in Table 2, it is evident that the maximum number of stolon per plant (24.00) was recorded under the treatment $180: 120 \mathrm{~kg}$ $\mathrm{N}$ : K/ha at harvesting. 
Table.1 Effect of nitrogen and potassium levels on growth parameters of potato

\begin{tabular}{|l|c|c|c|c|c|c|c|c|c|c|c|c|}
\hline Treatment & \multicolumn{4}{|c|}{ Plant height $(\mathrm{cm})$} & \multicolumn{4}{c|}{ No. of leaves } & \multicolumn{2}{c|}{$\begin{array}{c}\text { Fresh weight of } \\
\text { shoot (g) }\end{array}$} & \multicolumn{2}{c|}{$\begin{array}{c}\text { Dry weight of } \\
\text { shoot(g) }\end{array}$} \\
\hline & $\begin{array}{c}\text { 30 } \\
\text { DAS }\end{array}$ & $\begin{array}{c}\mathbf{5 0} \\
\text { DAS }\end{array}$ & $\begin{array}{c}\mathbf{7 0} \\
\text { DAS }\end{array}$ & $\begin{array}{c}\mathbf{9 0} \\
\text { DAS }\end{array}$ & $\begin{array}{c}\mathbf{3 0} \\
\text { DAS }\end{array}$ & $\begin{array}{c}\mathbf{5 0} \\
\text { DAS }\end{array}$ & $\begin{array}{c}\mathbf{7 0} \\
\text { DAS }\end{array}$ & $\begin{array}{c}\mathbf{9 0} \\
\text { DAS }\end{array}$ & $\begin{array}{c}\mathbf{7 0} \\
\text { DAS }\end{array}$ & $\begin{array}{c}\text { At } \\
\text { Harvesting }\end{array}$ & $\begin{array}{c}\text { 70 } \\
\text { DAS }\end{array}$ & $\begin{array}{c}\text { At } \\
\text { Harvesting }\end{array}$ \\
\hline T1 & 14.23 & 24.60 & 28.35 & 26.68 & 4.53 & 13.06 & 17.87 & 15.53 & 51.70 & 87.08 & 6.72 & 14.10 \\
\hline T2 & 17.77 & 27.27 & 31.87 & 29.86 & 10.60 & 18.13 & 21.07 & 19.40 & 83.89 & 107.82 & 8.91 & 16.72 \\
\hline T3 & 19.00 & 28.07 & 32.75 & 31.08 & 11.33 & 18.80 & 21.60 & 19.93 & 90.60 & 121.19 & 9.84 & 17.84 \\
\hline T4 & 20.30 & 29.73 & 33.53 & 32.20 & 12.35 & 20.40 & 22.53 & 20.87 & 113.94 & 129.43 & 10.89 & 18.85 \\
\hline T5 & 15.43 & 25.80 & 29.30 & 28.30 & 5.80 & 21.53 & 18.47 & 16.13 & 71.99 & 119.49 & 7.64 & 15.35 \\
\hline T6 & 16.03 & 26.87 & 30.20 & 29.20 & 7.06 & 22.93 & 19.90 & 20.57 & 92.80 & 125.81 & 8.63 & 16.14 \\
\hline T7 & 21.80 & 30.27 & 37.12 & 37.11 & 16.26 & 26.87 & 26.47 & 25.13 & 121.12 & 133.67 & 18.09 & 22.01 \\
\hline T8 & 24.60 & 32.33 & 38.67 & 38.33 & 19.00 & 31.80 & 35.38 & 29.38 & 143.92 & 144.86 & 22.90 & 24.54 \\
\hline
\end{tabular}

Table.2 Effect of nitrogen and potassium levels on yield attributing parameters of potato

\begin{tabular}{|c|c|c|c|c|c|c|c|}
\hline \multirow[t]{2}{*}{ Treatment } & \multicolumn{2}{|c|}{ No. of stolon/plant } & \multicolumn{2}{|c|}{$\begin{array}{l}\text { Fresh weight of } \\
\text { tuber (g) }\end{array}$} & \multicolumn{2}{|c|}{$\begin{array}{l}\text { Dry weight of tuber } \\
\text { (g) }\end{array}$} & \multirow{2}{*}{$\begin{array}{c}\text { Yield/plot } \\
(\mathrm{kg}) \\
\text { At } \\
\text { harvesting } \\
\text { (kg/ha) }\end{array}$} \\
\hline & $\begin{array}{c}70 \\
\text { DAS }\end{array}$ & $\begin{array}{c}\text { At } \\
\text { Harvesting }\end{array}$ & 70 DAS & $\begin{array}{c}\text { At } \\
\text { Harvesting }\end{array}$ & $\begin{array}{c}70 \\
\text { DAS }\end{array}$ & $\begin{array}{c}\text { At } \\
\text { Harvesting }\end{array}$ & \\
\hline T1 & 9.00 & 11.67 & 83.46 & 337.09 & 27.87 & 29.75 & 5.22 \\
\hline T2 & 11.33 & 15.00 & 150.57 & 524.11 & 46.68 & 41.55 & 6.14 \\
\hline T3 & 13.00 & 16.33 & 182.68 & 548.23 & 47.81 & 54.12 & 7.16 \\
\hline T4 & 14.00 & 17.67 & 219.47 & 631.21 & 50.42 & 78.26 & 7.43 \\
\hline T5 & 10.00 & 13.00 & 132.74 & 439.37 & 29.29 & 32.01 & 7.73 \\
\hline T6 & 11.00 & 14.00 & 141.33 & 478.57 & 30.93 & 38.13 & 8.13 \\
\hline $\mathrm{T7}$ & 17.67 & 21.33 & 261.57 & 646.19 & 56.62 & 146.74 & 8.31 \\
\hline T8 & 20.67 & 24.00 & 295.44 & 701.84 & 67.89 & 183.92 & 8.79 \\
\hline
\end{tabular}

The minimum number of stolon per plant (11.67) was counted in the treatment $0 \mathrm{~kg}$ $\mathrm{N} / \mathrm{ha}$, and $0 \mathrm{~kg}$ potash at harvesting. At harvest, fresh weight of tuber per plant ranged from minimum of $337 \mathrm{~g}$ to maximum of $701.84 \mathrm{~g}$.

The maximum dry weight of tuber per plant $(183.92 \mathrm{~g})$ was noted on application of $180: 120 \mathrm{~kg} / \mathrm{ha}$ of $\mathrm{N}: \mathrm{K}$ at harvesting. With regard to the yield data, presented in Table 2, it can be inferred that highest tuber yield per plot was $8.79 \mathrm{~kg}$ at treatment combination $180: 120 \mathrm{~kg} / \mathrm{ha}$ of N: K.
Thus, from the above findings, it can be summarized that increasing quantity of nitrogen significantly increased all the growth characters, yield attributes and tuber yield.

It may be also concluded on the basis of research findings that use of $120 \mathrm{~kg} \mathrm{~K} / \mathrm{ha}$ be adopted for progressive growth and well development of tubers under irrigated ecosystem. Application of $120 \mathrm{~kg} \mathrm{~K} / \mathrm{ha}$ produced higher tuber yield (203.42q/ha) as compared to other doses of potassium. The interaction was significant in all the growth and yield attributing characters including dry 
weight of shoot and roots. However, the highest tuber yield (219.92q/ha).

\section{Acknowledgement}

The authors acknowledge the contributions of DP Mechao, and Sunita Bhandari, Department of Agronomy, Uttaranchal (P.G) College of Bio- Medical Sciences and Hospitals, H.N.B Garhwal University, Srinagar (Garhwal), Uttarakhand (India) for their technical support and valuable contributions to the manuscript.

\section{References}

Bhat, M.M., Lankar, G.M., Ahmaed, N. and Gupta, A.J. 2005. Response of potato cultivars to varying levels of nitrogen and Phosphorous. Journal of research, SKUAST.4 (2): 164-169

Bose, U.S. Bisen A. and Nayak, S. 2008: Effect of different levels of nitrogen and potassium on growth and yield of potato (Solanum tuberosum L.), Green farming. 2 (1): 16:17.

Chettri, M., Basu, A., Konar, A. and Mondal, A.B., 2005, Effect oforganic sources of nutrients on potato production in West Bengal. Potato J., 32(3-4): 163-164

Chettri, M., Mondal, S.S. and Roy, B., 2002, Influence of potassium and sulphur with or without FYM on growth, productivity and disease index of potato in soils of West Bengal. J. Indian Potato. Assoc., 29(1-2): 61-65.

Chopra, S., Gupta, A.K., Bhat. D.J and Rafiq, R. 2010, Uptake studies and yield effects in potato variety Kufri Bhadshah in response to varying levls of nitrogen and potassium.Journal of Hills Agriculture 1 (1): 40-42

Chopra, S., Kanwar, J.S. and Samnotra, R.K. 2006. Effect of different levels of nitrogen and potassium on growth, yield and biochemical composition of potatoes, variety Kufri Jawahar. Environmental and Ecology.24 (2): 268-271.

Fasil, K., Niguse, A.M. and Abereha. Effect of potassium on tuber yield and yield component of potato (Solanum tuberosum) on loamy soils of Atsbiwenberta, Tigray, Ethiopia. Journal of Biology, Agriculture and Healthcare. Vol.6, No.3.

Gathungu, G.K., Shibairo, S.I., Gidhiri, S.M., Mburu, M.W.K., Ojimbo, P.S. and Kidanemarian, H.M. 2000. Effect of source, time and method of nitrogen application on growth and yield components of potato in keneya, African crop science Journal. 8 (4): 387-402.

Hamedani, M.Y. 2003. A study of the effect of nitrogen rate on yield; yield components and nitrate accumulation in potato varieties. Iranian Journal of Agricultural sciences.34 (4): 977-985.

IslamPulok, M.A., Roy, T.S., Haque, M.N., Hossain khan, M.S. and Parvez, M.N. (2016).Grading of Potato Tuber as Influenced by Potassium Level and Mulch Materials. Focus on Sciences, Volume 2, Issue 4

Karam, F., Lahour, R., Massad, R., Stephan, C., Rouphael, Y. and Colla, G., 2005, Yield and tuber quality of potassium related potato under optimum irrigation. Acta-Horti., 68(4): 103-108.

Kavvadias, V., Paschalidis, C., Paraskevopoulos, A. and Stavrihos, E., 2002. Response of potato cv. Spunta to nitrogen and magnesium fertilization. Pochvoznanie, Agrokhimiya-iEkologiya.37 (4): 26-29.

Kelling, K., Stevenson, W., Speth, P., and Vaughan, J. 2016. Interactive effects of fumigation and fungicides on potato response to nitrogen rate or timing. American Journal Potato Research, 93:533-542. 
Khan, M. Z., Akhtar, M. E., Safdar, M. N., Mahmood, M. M., Ahmad, S. and Ahmed, N. (2010). Effect of source and level of potas on yield and quality of potato tubers, Pak. J. Bot., 42(5): 31373145

Khan, M. Z., Akhtar, M. E., Safdar, M. N., Mahmood, M. M., Ahmad, S. and Ahmed, N. (2010). Effect of source and level of potas on yield and quality of potato tubers, Pak. J. Bot., 42(5): 31373145.

Khandakhar, S.M.A.T., Rahman, M.M., Uddin, M.J., Khan, S.A.K.U. and Quddus, K.G., 2004, Effect of lime and potassium on potato yield on acid soil. Pakistan J. Bio. Sci., 7(3): 380-383.

Rai, G.K. Verma, M.M. and Singh J. 2004. Effect of potassium and nitrogen on yield and quality of potato (Solanum tuberosum L.) tubers. Indian journal of Agriculture Biochemistry. 17(1): 45-46.

Sharma R.C and Sood, M. C. 2002. Nitrogen and Potassium interaction on tuber yield, quality and organic carbon status of Shimla soils. Potato, Global Research \& Development, Proceeding of global conference on potato, New Delhi, India volume 2: 843-851.

Singh S.K. and Lal, S.S. 2012. Effect of potassium levels and its uptake on correlation between tuber yield and yield attributing characters in potato (Solanum tuberosum L.) var. Kufripukhraj, Asian Journal of Horticulture. 7 (2): 392-396.

Singh, N.P. and Raghav, M. (2000). Response of potato to nitrogen and potassium fertilization under U.P tarai conditions. J. Indian Potato Assoc. 27:47-48

\section{How to cite this article:}

Mechao, D.P. and Sunita Bhandari. 2018. Evaluation of Response of Potato on Different Doses of Nitrogen and Potassium in Growth and Yield. Int.J.Curr.Microbiol.App.Sci. 7(11): 23502354. doi: https://doi.org/10.20546/ijcmas.2018.711.265 